\title{
VIE ET AVENTURES DE GASPARD HAUSER L'IDIOT DE NUREMBERG (1860)
}

Aus der Kolportage Vie et aventures de Gaspard Hauser l'idiot de Nuremberg, Paris [1860].

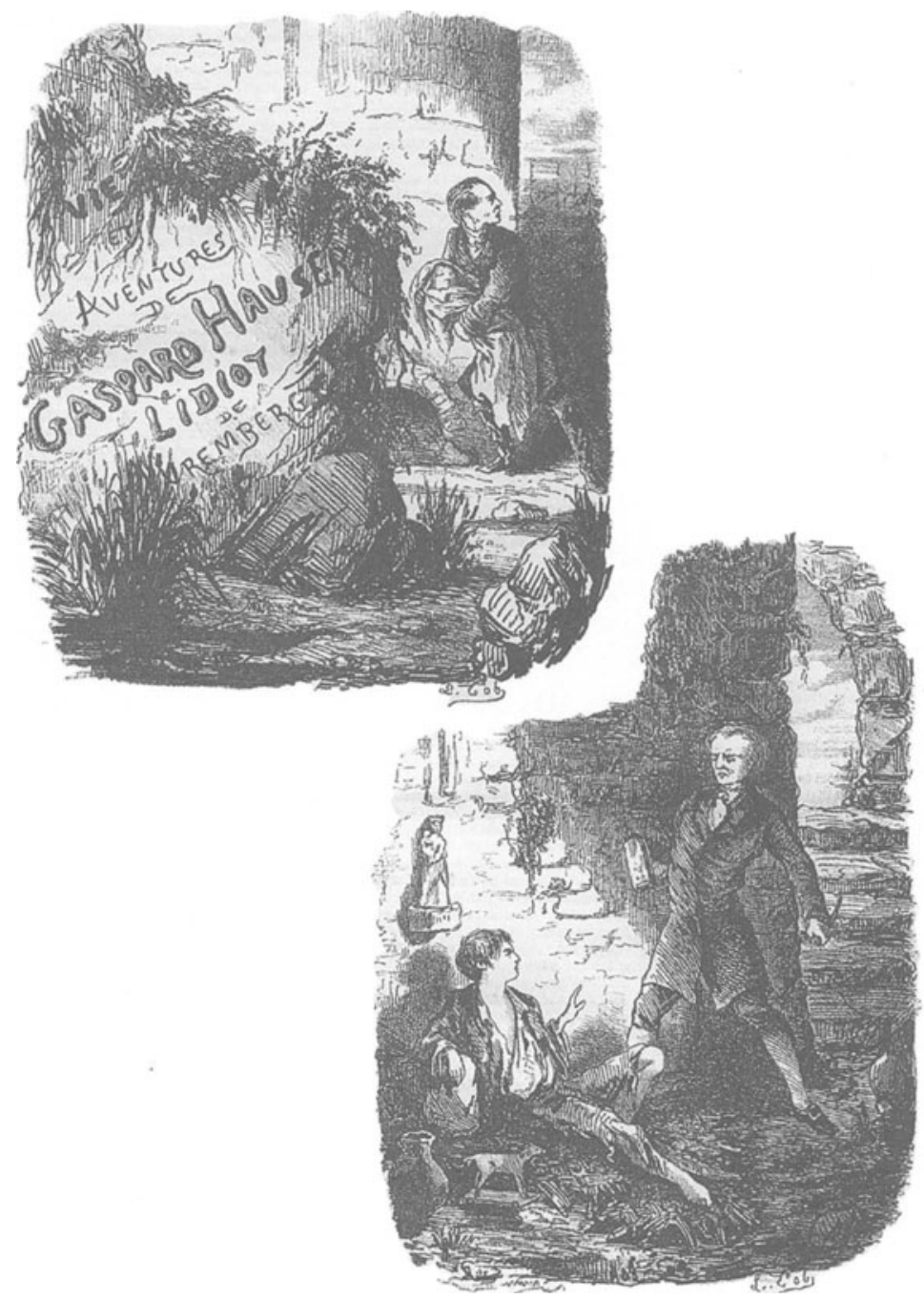

